\title{
AFGHAN MIGRATORY STRATEGIES AND THE THREE SOLUTIONS TO THE REFUGEE PROBLEM
}

\author{
Dr Alessandro Monsutti*
}

The present article proposes three main theses: the normality of movements and the prior existence of transnational networks in and around Afghanistan; the resilience and inventiveness of the Afghan population, especially illustrated by the remittance system; the relevance of migratory movements and of transnational networks for the reconstruction of the country and the stability of the region. In contrast to the migratory strategies developed by the refugees, the three solutions to the problem of the refugees promoted by the UNHCR (voluntary repatriation in the country of origin; integration in the host country; resettlement in a third country) are based on the idea that solutions are found when movements stop. But mobility may be seen as a key livelihood strategy. A more comprehensive solution is needed, which takes into account the full range of strategies and responses developed by the Afghan population, including the back-and-forth movements between Afghanistan, Pakistan, Iran and beyond.

\section{The normality of movement}

The present article is based on data collected since the mid-1990s in Afghanistan, Pakistan and Iran, and then in Western countries, especially among the Hazaras, a marginal group originating in the centre of Afghanistan. ${ }^{1}$ Beyond some specificity, their migratory networks express some more widespread social features and reflect old patterns of mobility.

Afghans give different and usually plural reasons for their decision to migrate: perhaps an outbreak of fighting, the danger of bombing or compulsory conscription, or a threat from a personal enemy; perhaps the search for work or opportunities to trade, the need for medical treatment, or the undertaking of a pilgrimage. My main aim here, however, is not to highlight these motives in

\footnotetext{
* The author is currently Senior Lecturer at the Graduate Institute of International and Development Studies in Geneva. He is also a research associate at the Refugee Studies Centre (University of Oxford) and at the Laboratoire d'anthropologie des institutions et des organisations sociales (CNRS-EHESS, Paris).

1 The data have been collected during several field researches in Afghanistan, Pakistan, Iran, Europe, North America, Australia and New Zealand conducted since 1993 on Afghan transnational networks and migratory strategies, in particular for a project entitled Beyond the Boundaries: Hazara Migratory Networks from Afghanistan, Pakistan and Iran toward Western Countries, supported by the MacArthur Foundation (Chicago) between 2004 and 2006. It also draws upon a series of team studies carried out by the Afghanistan Research and Evaluation Unit (Kabul) and funded by the UNHCR and the European Commission (EC) for which the author worked as project adviser.
}

Refugee Survey Quarterly, Vol. 27, No. 1 C UNHCR [2008]. All rights reserved.

For Permissions, please email: journals.permissions@oxfordjournals.org

DOI:10.1093/rsq/hdn007 
a context of diffuse insecurity but to describe how transnational networks and ongoing mobility are at the chore of the strategies developed by many Afghans. A study of individual trajectories and family strategies shows that few Afghans have never left their country since the Communist coup d'etat of 1978 and the Soviet intervention of 1979 , and also that many have returned at some point for at least a short visit. The leaving and coming back has been constant.

While the Afghans have constituted the largest refugee population in the 1980s and 1990s, we are a long way from the figure of the victim compelled to leave his or her homeland in the face of a towering threat, with the vague hope of one day being able to return. Although migratory movements acquired an unprecedented scale during the war, they have existed for a long time in one form or another - and have remained in the memory of the members of many Afghan communities. Nor do they necessarily have the traumatic significance that is often attributed to them; individual mobility and the dispersion of families or mutual support groups are not experienced as destructuring phenomena in and of themselves. Seen through this prism, the concepts of "economic migrant", "political refugee", "country of origin", "host country", "voluntary" or "forced" migration, or even "return", appear singularly reductionist in the Afghan context. All these categories overlap with a combined presence of political, cultural, economic and ecological factors.

Based on ethnographic evidences, the present article will propose three main theses: the normality of movements and the prior existence of transnational networks in the region; the resilience and inventiveness of the Afghan population, especially illustrated by the remittance system; the relevance of migratory movements and of transnational networks for the reconstruction of Afghanistan (for both economy and social life). My intention is to contrast these migratory strategies with the three solutions to the problem of the refugees promoted by the United Nations High Commissioner for Refugees (UNHCR): voluntary repatriation in the country of origin; integration in the host country; resettlement in a third country. They are based on the idea that solutions are found when movements stop. But mobility may be seen as a key livelihood strategy. Policywise, a more comprehensive solution is needed, which takes into account the full range of strategies and responses developed by the Afghan population, including the back-and-forth movements between Afghanistan, Pakistan, Iran and beyond. ${ }^{2}$

Through the action of the Afghanistan Comprehensive Solution Unit (ACSU), the UNHCR had become progressively aware of the necessity to develop a new paradigm supplementing the historical mandate of protection and assistance. ${ }^{3}$ Such a perspective reflects both a changing political context

See E. Stigter and A. Monsutti, Transnational Networks: Recognising a Regional Reality, Kabul, Afghanistan Research and Evaluation Unit, 2005.

3 Such an evolution is clearly visible in internal documents like Towards a Comprehensive Solution for Displacement from Afghanistan, Geneva, United Nations High Commissioner for Refugees (Discussion Paper), 2003, and Afghanistan: Challenges to Return, Geneva, United Nations High Commissioner for Refugees, 2004. 
(with the Soviet withdrawal and the end of the Cold War, the subsequent conflict between factions, the rise and fall of the Taliban and the establishment of a government backed by the international community in Kabul) and a progressive learning from social realities (mobility as an asset and not only as a problem).

\section{Beyond the unprecedented wave of return}

Migration is part of the Afghan social and cultural landscape. Seasonal movements of nomads who bring their herds to better pasture lands, but who take the opportunity to trade with sedentary farmers; mountain people who go to urban centres or to lowlands in order to find any menial job; and pilgrims, soldiers or refugees, Afghans have had a long history of migration in its various forms.

The war which has torn apart Afghanistan after the Communist coup of April 1978 and the Soviet invasion of 1979 has nevertheless given a more dramatic and massive dimension to those movements of populations. At the beginning of the 1990s Afghans formed the most numerous refugee group in the world, accounting for nearly half the total falling under the mandate of the UNHCR. ${ }^{4}$ In 1990 a peak of 6.22 million Afghan refugees was reached. Large numbers returned after the Soviet withdrawal (1989) and the capture of Kabul by resistance forces (1992), but over the following years this trend was partially reversed as more outward flows accompanied the new outbreaks of fighting, especially in the Mazar-e-Sharif and Kabul regions.

The attacks on the World Trade Centre and the Pentagon in September 2001 and the subsequent intervention of an international coalition led by American forces, bringing about the fall of the Taliban in late 2001 and the establishment of a government in Kabul backed by the international community in winter 2001-2002, set the stage for a new era filled with hope for peace and prosperity. The prospect of a restoration of normality has caused an unprecedented wave of repatriation. According to official figures, more than five million Afghans have returned to their country either with the assistance of the UNHCR or spontaneously, mostly from Pakistan and Iran. Another half million internally displaced people have regained their village of origin. Afghanistan has been one of the largest repatriation campaigns in the history of the UN agency.

But following a new deterioration of the security situation, the pace of repatriation has dropped since 2005. Afghanistan continued to be the leading country of origin of refugees with approximately three million people of Afghan descent living between Pakistan and Iran. Even without including 1.3 million Afghans living outside the camps, Pakistan is still the asylum country with the single largest number of refugees worldwide, followed by Iran. By the end of 2006, both countries together hosted 20 per cent of the world's refugee population. ${ }^{5}$ Many of the remaining Afghans have been living outside their country of

\footnotetext{
4 R. Colville, “Afghan Refugees: Is International Support Draining Away After Two Decades in Exile?,” Refuge, Vol. 17, 1998, 6 .

52006 Global Trends: Refugees, Asylum-seekers, Returnees, Internally Displaced and Stateless Persons, Geneva, United Nations High Commissioner for Refugees, 6-7.
} 
origin for more than two decades and more than 50 per cent were born abroad. The UNHCR acknowledges that they have become used to different living conditions and that many originate from areas currently affected by insecurity and poverty. Voluntary repatriation, which takes place within the framework of the tripartite agreements signed by UNHCR and the Governments of Afghanistan, Pakistan and Iran, is nevertheless still considered to be the preferred durable solution. ${ }^{6}$

The level of repatriation initially showed a degree of confidence in the renascent state, but also reflected expectations created by donor pledges to rebuild the country and the deterioration of living conditions in the places of refuge. To a certain degree, it had also been affected by the Iranian and Pakistani authorities increasingly implementing policies to encourage Afghans to return home. The sustainability of such a large return movement has been questioned by many. Turton and Marsden, ${ }^{7}$ for instance, assess the repatriation operation, reintegration opportunities, and the role and interests of the international community. They stress the fact that many registered returnees may be "recyclers", repatriating to Afghanistan, getting the assistance package and then going back to Pakistan or Iran. Some others may be seasonal migrants with no intention of staying in Afghanistan on a long-term basis. They also drew attention to the difficulties returnees faced in resettling leading to a "backflow" of returnees to Iran and Pakistan and further movement within Afghanistan.

Return to Afghanistan does not necessarily mean the end of displacements and may prompt onward passage, following a pattern of multidirectional crossborder movements. Channels of pre-established transnational networks exist between Afghanistan, Pakistan and Iran, as the movement of individuals to seek work, to escape drought or to flee war has been a common experience in the whole region. Despite the high levels of repatriation, the number of Afghans living abroad is still considerable. Families and individuals continue to move, and it seems unlikely that the back-and-forth movements will stop while they constitute a key livelihoods strategy. Many Afghans have been shifting from one place to the next for years - some never returning to their place of origin, others only on a temporary basis before deciding to return into Iran, Pakistan or further afield. Young men in particular, who have not travelled before, are still choosing to leave Afghanistan - suggesting that displacement is not only caused by conflict. ${ }^{8}$

With the passing of time, the Afghans have woven very efficient migratory networks based on back and forth movements and the dispersion of the members

\footnotetext{
See www.unhcr.org (last visited 30 October 2007).

7 D. Turton and P. Marsden, Taking Refugees for a Ride? The Politics of Refugee Return to Afghanistan, Kabul, Afghanistan Research and Evaluation Unit, 2002.

8 For young Hazara male migrants for instance, migration between the mountains of Central Afghanistan and the cities of Iran offers the opportunity to broaden their social networks beyond narrow kinship and neighbourhood ties. It may be conceived as a necessary stage in their existence, a rite of passage to adulthood and a step toward manhood. See A. Monsutti, "Migration as a Rite of Passage: Young Afghans Building Masculinity and Adulthood in Iran”, Iranian Studies, Vol. 40, April 2007, 167-85.
} 
of the kin groups between Afghanistan, Iran, Pakistan and beyond. After many years, the migratory movements are highly organized, and the transnational networks became a major, even constitutive, element in the social, cultural and economic life of Afghans. One of the most striking aspects of this migration is the huge flow of capital that it draws towards Afghanistan. Once they are in Pakistan, in Iran or elsewhere, the Afghans have to solve the technical problem of sending money they have saved to their family in Afghanistan. Official channels became progressively available after 2002, but the problem was especially acute in the 1980s and 1990s, when no banks were operational.

Migration to Afghanistan's neighbouring countries, and the very significant sum of remittances sent home, can be seen not only as a response to war and insecurity, but also as an efficient economic strategy for households and a crucial contribution to the economy of the country as a whole. There is a clear pattern of multidirectional cross-border movements that indicates the ongoing, cyclical nature of migration - blurring the boundaries between refugees and voluntary migrants. ${ }^{\text {m }}$

\section{Refugee motivations and vintages}

Several authors have argued that a typology is integral to any general theory of migration and refugee displacement. Migration tends then to be conceived through the lens of motivations, forced migration being a specific, somehow extreme, case where the agency is minimal. Kunz, for instance, starts with the following definition of the refugee: "With a different past and with motivations at variance with those affecting voluntary migrants, the refugee moves from his homeland to the country of his settlement against his will. He is a distinct social type", ${ }^{10}$ whose aim is one day to rediscover community ties by returning to his homeland. Kunz's central distinction is between voluntary and involuntary migration (characterized by push and pull factors, respectively) and he uses a classical decision model to identify the diverse combinations of motives and external circumstances. Thus, he speaks of "anticipatory refugee movement", where refugees move to the host country in anticipation of a worsening situation at home, and "acute refugee movement", where they flee, often in difficult conditions, a context of violence and insecurity. In both cases, it is true, "push

9 On those questions, see A. Monsutti, "Cooperation, Remittances, and Kinship among the Hazaras", Iranian Studies, Vol. 37, 2004, 219-40; War and Migration: Social Networks and Economic Strategies of the Hazaras of Afghanistan, New York \& London, Routledge, 2005; and E. Stigter and A. Monsutti, Transnational Networks, op. cit. See also M. J. Hanifi, "Anthropology and the Representations of Recent Migrations from Afghanistan”, in E. M. Godziak and D. J. Shandy (eds), Rethinking Refuge and Displacement: Selected Papers on Refugees and Immigrants, Vol. 8, Arlington, American Anthropological Association, 2000, 291-321. This author considers in a historical perspective the political economy of the whole region of which Afghanistan is a part. He argues that all the Afghans who left their country in the 1980s and 1990s cannot be univocally labelled as refugees, as they have followed ancient patterns of economic migration.

10 E. F. Kunz, "The Refugee in Flight: Kinetic Models and Forms of Displacement", International Migration Review, Vol. 7, 1973, 130; see also E. F. Kunz, "Exile and Resettlement: Refugee Theory", International Migration Review, Vol. 15, 1981, 42-51. 
factors" are the decisive ones, but the urgency gives them much greater prominence in "acute movement". Pull factors may then often play a role in the choice of an (at least temporary) host country.

Inspired by such a model, Connor ${ }^{11}$ focuses on the many Afghans who settled outside the refugee villages within the urban fabric of Pakistan. Her work on the "self-settled refugees" in Peshawar starts from the assumption that choice of residence is influenced by the refugee's past history and cultural framework, including geographical and ethnic origin, social position (educational level, occupational experience) and political involvement (membership of a resistance movement), time of departure from Afghanistan, and reasons for the decision. Connor seeks to close the gap between studies of voluntary migrants and refugees, and to move beyond the idea that the route taken by the latter is always "forced, chaotic, generally terror-stricken". Following Kunz, she argues that a general theory of refugees must formulate causal typologies and include the notion that different "vintages" of refugees share a number of distinct characteristics. ${ }^{12}$ She shows that Afghans left their country after events related in some way to their own particular sociology; they did not flee en masse.

The results of the research are expressed in percentages on the motivations to migrate, correlated with the year of departure. After analysing the responses of 771 heads of families, she identifies ten reasons for the decision to leave Afghanistan: fear for life (14.53 per cent) or livelihood ( 9.86 per cent) in the wake of bombing and military hostilities; avoidance of conscription (23.48 per cent); anti-Communism (12.06 per cent); recent imprisonment (8.82 per cent) or fear of arrest (6.74 per cent); suspect family member (3.76 per cent); harassment due to membership of a pro-Communist organization (2.98 per cent); being in Pakistan at the time of the 1978 coup ( 0.91 per cent); other reasons (1.82 per cent).

It is beyond question that each wave of refugee displacement can be differentiated on the basis of the existing and potential threats faced by people at that time, while correlations can be made between ethnic identity, gender and age. Although, generally speaking, Afghans have fled from war, their reasons for migration and the actual dynamics of this movement are much more nuanced. The physical effects of war may be differentiated from the disruption of traditional livelihoods, the political and ethnic repercussion of war and the economic fallout caused by war.

Connor admits that she pays greater attention to what Afghans say than to what they do. She spends little time on the religious dimension of a protest exodus against the Communist government. Her conclusion, in which it is certainly possible to follow her, is that Afghans left their country after events

11 See K. M. Connor, An Analysis of Residential Choice Among Self-Settled Afghan Refugees in Peshawar, Pakistan, Lincoln \& Omaha, University of Nebraska, 1987; "Rationales for the Movement of Afghan Refugees to Peshawar", in G. M. Farr and J. G. Merriam (eds), Afghan Resistance: The Politics of Survival, Boulder and London, Westview Press, 1987, 151-90; "Factors in the Residential Choices of Self-Settled Afghan Refugees in Peshawar, Pakistan”, International Migration Review, Vol. 23, 1989, 904-32.

12 K. Connor, "Rationales for the Movement of Afghan Refugees to Peshawar", op. cit., 155. 
related in some way to their own particular sociology. Her mapping of Afghan refugees in Peshawar is most interesting, but the significance of her information on the reasons for departure from Afghanistan is open to some doubt. In fact, the results are rather disappointing.

It comes as no surprise that the bombing and fighting, together with general pressure from the Soviet army and the Communist government, were the main reasons driving Afghans into exile (rural populations were more likely to suffer bombing and massacre, whereas city dwellers had more to fear from wrongful arrest). The percentages given by Connor do not take account of the inevitable overlap in motives. Moreover, her chronological section focuses particularly on the moment of departure; she does not notice that people have not stopped moving while they arrived to Peshawar, says nothing about back and forth movements, and takes no interest in refugee movements within a diachronic perspective. She gives the impression that Afghans left at a precise moment and for precise reasons, which might certainly have varied from person to person or group to group but were unambiguous in each particular case, whereas in reality the taking of decisions was an uninterrupted process.

Motivations and causes overlap. People may live Afghanistan for protectionrelated reasons, but seek work in Iran or Pakistan. While abroad, they have the chance to improve their income and access comparatively better medical facilities, and in this time they reassess their priorities. The motivation to support the household is often combined with more personal reasons such as, for young men, the urge to seek new experiences or earn money to show that they can fulfil their marital responsibilities.

Categorization by "date of departure" does not allow us to draw out medium to long-term strategies. It was one thing to leave Afghanistan, and another to choose not to return. In seeking to group refugees by "vintage" and by social-cultural, status and ethnic factors, ${ }^{13}$ Connor neglects the planned "multilocation" of the members of domestic units and kinship groups, as well as the complementarity of places of residence and occupations. Driven by poverty as much as by war, Afghans have been constantly on the move. They have woven an intricate web of transnational relations, and it would be pointless to try to specify the moment at which the decision to leave Afghanistan was taken.

Migration is also a way of spreading risk within a household (with more than one son) or between household (of various brothers). It is a coping strategy to cover basic needs and repay debts through remittances. The migration of individual members of a household may allow for their family to stay in their area of origin. For single migrant workers the availability of pre-established transnational networks facilitates the migration and influences the place of destination. Most Afghans living and working in Iran have brothers staying behind with their parents in Afghanistan, and they see their migration as a coping

13 K. M. Connor, "Factors in the Residential Choices of Self-Settled Afghans Refugees in Peshawar, Pakistan", op. cit., 927-9. 
strategy that allows their family to receive remittances to pay for daily needs, and to accumulate capital for investment in land and housing.

Factors which induce migration cannot be reduced to the explicit motivations of social actors. Furthermore, they are not necessarily the same as those which perpetuate it. Migrants weave networks of contacts that make it easier to move between different countries. Addressing the causes of migration does not constitute a guarantee to bring it to an end, as the factors sustaining migratory flows come to form more or less stable systems.

\section{Transnational networks and social strategies}

A recent and growing body of literature proposes a novel approach to migration and mobility contrasting with typologies. Several scholars have applied the concept of transnational social networks to the study of specific refugee groups. ${ }^{14}$ Without negating the specificity of refugees in legal terms or minimizing the hardships they face, these authors borrow methodological and theoretical concepts developed mainly for the study of labour migration. This approach stems from the concern that refugees are not mere victims but people adapting to the world system, using their social and cultural resource. Refugees and other types of migrants share a number of social features, and individuals may belong to several categories at a time or successively. Social networks almost always include people who can be labelled as labour migrants or as refugee, and migratory circuits are often multidirectional. This new trend is also influencing research on Afghan refugees. A number of texts have been published on the Afghan diaspora settled in Western countries ${ }^{15}$ and the networks existing between distant locales and scattered people are increasingly studied. ${ }^{16}$ It appears that migratory trajectories of Afghans are not definitive nor linear. It would be more accurate to describe them as a series of multidirectional displacements. This phenomenon

14 See for instance N. Al-Ali, R. Black, Kh. Koser, "Refugees and Transnationalism: The Experience of Bosnians and Eritreans in Europe", Journal of Ethnic and Migration Studies, Vol. 27, 2001, 615-34; G. Chatelard, Iraqi Forced Migrants in Jordan: Conditions, Religious Networks, and the Smuggling Process, Florence, Robert Schuman Centre for Advanced Studies, European University Institute (Working Papers 49), 2002; S. Shami, "Transnationalism and Refugee Studies: Rethinking Forced Migration and Identity in the Middle East”, Journal of Refugee Studies, Vol. 9, 1996, 3-26.

15 P. Centlivres and M. Centlivres-Demont, "Exil et diaspora afghane en Suisse et en Europe", Cahiers d'études sur la Méditerranée orientale et le monde turco-iranien, Vol. 30, 2000, 151-71; P. Centlivres, M. CentlivresDemont and T. Gehrig, "La diaspora afghane: le paradoxe apparent de l'identité et de l'intégration", in P. Centlivres and I. Girod (eds), Les défis migratoires: actes du colloque CLUSE, Neuchâtel 1998, Zurich, Seismo, 2000, 272-8; P. A. Omidian, "Life Out of Context: Recording Afghan Refugees' Stories", in L. A. Camino and R. M. Krulfeld (eds), Reconstructing Lives, Recapturing Meaning: Refugee Identity, Gender, and Culture Change, Basel, Gordon and Breach Publishers, 1994, 151-78; P. A. Omidian and J. G. Lipson, "Elderly Afghan refugees: traditions and transitions in Northern California", in P. A. De Voe (ed.), Selected Papers on Refugee Issues, Washington, DC, Committee on Refugee Issues (American Anthropological Issues), 1992, 27-39; A. C. Shalinsky, "Gender Issues in the Afghanistan Diaspora: Nadia's Story", Frontiers: A Journal of Women Studies, Vol. 17, 1996, 102-23. There are other ongoing researches and further publications are forthcoming, for instance by Angela Schlenkhoff and Ceri Oeppen on Afghans in the UK and the United States.

16 See A. Monsutti, "Cooperation, Remittances, and Kinship among the Hazaras", op. cit.; War and Migration, $o p$. cit. There is also a series of reports on transnational networks published by the Afghanistan Research and Evaluation Unit (accessible on their homepage: www.areu.org.af). 
has become an encompassing aspect of the Afghan way of life and it implies an intense circulation of people and goods across international borders.

In order to describe the interplay of local and global forces and to understand how the Afghan migrants are linked to the world system, three methods of observation and analysis seem relevant: an open and flexible use of the proven concept of network; a focus on the production and distribution of commodities; multisited ethnography and transnational studies. The concept of network has been defined by Barnes more than 50 years ago in a very simple and still workable way:

The image I have is of a set of points some of which are joined by lines. The points of the image are people, or sometimes groups, and the lines indicate which people interact with each other. We can of course think of the whole of social life as generating a network of this kind. ${ }^{17}$

It has been reformed and adapted to the globalization context by Hannerz, ${ }^{18}$ who has reduced the weight of individuals and attached considerably greater scope to the strategies of groups such as households, lineages, neighbourhood circles, or even tribal segments. E. Marx ${ }^{19}$ has established the usefulness of the concept of network for understanding the experience of refugees whose social ties are expanding in different locales. The study should not concentrate only on permanent institutionalized relations, as passing ties also hold essential information about social practices. In the Afghan case, this meant going beyond the apparent weight of official kinship relations and ancestral, tribal or ethnic affiliation, in order to bring out the actual relations of cooperation mobilized by the people in a context of insecurity and mobility.

The focus on networks and people remains nevertheless insufficient. Studying objects and their social meanings, and describing the production and distribution of a set of services and commodities have proven to be a fruitful approach. Exchanges do not only satisfy material needs, but produce and reproduce social ties. The relation between commodity flows and social ties is then reciprocal.

These two cogent methodological devices are encompassed in the concept of multi-sited ethnography defined by Marcus who talks of "tracking” strategies and who proposes different ways to apply his program: "follow the people", "follow the thing", "follow the metaphor", "follow the plot, story, or allegory", "follow the life or biography", and finally "follow the conflict". ${ }^{20}$ As Rouse states in his research on Mexican migration in the United States:

$[T]$ hrough the continuous circulation of people, money, goods, and information, the various settlements have become so closely woven together that,

J. A. Barnes, "Class and Committee in a Norwegian Island Parish", Human Relations, Vol. 7, 1954, 43.

18 U. Hannerz, "The Global Ecumene as a Network of Networks", in A. Kuper (ed.), Conceptualizing Society, London, Routledge, 1992, 34-56.

19 E. Marx, "The Social World of Refugees: A Conceptual Framework”, Journal of Refugee Studies, Vol. 3, 1990, 189-203.

20 G. Marcus, "Ethnography in/of the World System: the Emergence of Multi-Sited Ethnography", Annual Review of Anthropology, Vol. 24, 1995, 94-117. 
in an important sense, they have come to constitute a single community spread across a variety of sites, something I refer to as a "transnational migrant circuit". 21

A research which follows such an agenda will bring other outputs than the typological perspective which is about motivations and distinguishes vintages among refugees and migrants. Here, the study does not focus on any one location nor on the moment of departure, but considers - both diachronically and synchronically - migratory circuit as a whole.

\section{Multi-sited research on strategies}

It seems then worth tracking the strategies in spite of reconstructing the motivations, asking how rather than why people migrate. Adopting such a perspective, the fieldwork is not carried out within a bounded territory but following mobile people. The limit of the social group which is studied is not defined at first. The itinerary of an initially small number of persons and their effective social ties is reconstructed step by step during the research. ${ }^{22}$

The effective relations of solidarity may be studied by describing three complementary phenomena: first, the spatial mobility of individuals, their transnational routes and the migrant smuggling rings (travelling is risky, involves trust relationships and implements common economic strategies); then, the transfer of goods and money, and the trading activities across international borders; finally, the circulation of information through visits, telephone, letters and e-mail. This corresponds to the study of the way people, money and commodities, and information circulate proposed by Rouse and it gives access to three strategies: (1) How people travel? How do they cross fighting zones and international borders? (2) How people send their savings from abroad to their family left home in Afghanistan? (3) How people communicate even if scattered and in spite of the absence of any modern facility (telephone, postal service, etc.) in Afghanistan?

In the first stage, the research has been conducted in Afghanistan, Pakistan and Iran, the three different locations having their own advantages and drawbacks.

1. The village of origin. Afghanistan is a devastated country. Insecurity and poverty, the lack of schools and hospitals are all major handicaps. Yet it is the homeland and many refugees have kept family ties and lands in

21 R. Rouse, "Mexican Migration and the Social Space of Postmodernism”, Diaspora, Vol. 1, 1991, 14.

22 Within such a theoretical framework, the empirical collection of data is a slow path. Qualitative methods are mostly used, such as participant observation (living among people to gather unsolicited information), unstructured interviewing, life histories and narratives of exile, genealogies and kinship charts, accounts of the negotiations leading to marriages, detailed figures of the amount, frequency and destination of remittances. The reliability of the data is established by cross-checking and comparing the collected information. Their relevance is asserted through regularity (i.e. when information is given independently by different people) and saturation (i.e. when no new information may be drawn from interviews or observation). See A. Monsutti, "En suivant les réseaux de Kaboul à New York: quelques réflexions méthodologiques sur la recherche ethnographiques parmi les migrants”, Ethnologies, Vol. 27, 2005, 33-53. 
Afghanistan. People live there among their own; the women, children and old people are not isolated. This makes it possible for a lot of men to leave their family when they go to Pakistan, to Iran or to the Arabian Peninsula. The cost of living is low, at least in the countryside, even though all manufactured goods have to be imported from Pakistan or elsewhere.

2. The refugee camps and cities of Pakistan. In Pakistan, the Afghans were able to move freely (at least in the 1980s and 1990s) but the professional activities available to them were scarce. Some Afghans have obtained a Pakistani identity card or even a passport. For instance, Quetta is a central hub for the spatial identity and migratory networks of the Hazaras. The city serves as a stopover, an assembly point and a place of refuge. If expulsions are under way in Iran, or if there is major fighting in Hazarajat, people know that there will always be a relative to welcome them in Quetta. Trade flows and human movement in both directions add up to an intense migratory continuum. On the other hand, the capital of Pakistani Baluchistan does not offer many occupational outlets.

3. Iranian urban centres (Tehran, Qom, Isfahan, Mashhad, etc.). Iran presents a striking contrast with Pakistan. The labour market seems to offer more possibilities but living conditions generally remain precarious. Since its position on the international scene prevented Iran to receive the kind of international aid that Pakistan allowed to be channelled to refugees, proper camps have been very thin on the ground. It is quite easy to find a relatively well-paid job (building industry, construction of roads, quarry, agriculture, etc.) by drawing upon family or tribal networks, but Afghans are mainly employed as unskilled workers and find that many activities are forbidden to them, while the constant danger of expulsion, harassment and police violence means that it is difficult for them to settle with their family on a permanent basis.

A growing number of Afghans also went in Europe, North America or Australia. In the 1980s and early 1990s, most of them were from upper and middle urban classes. But many rural people found their way to the West during the time of the Taliban. For instance, some Hazaras are now present in Washington, DC, New York and New Jersey, where they are taxi drivers or are active in the catering industry (several have a pushcart or even a fried chicken shop). Many others preferred to go eastwards and tried their chance crossing illegally the sea between Indonesia to Australia on small fishing boats. ${ }^{23}$

My travels from Pakistan to Afghanistan and Iran, from Europe to North America, Australia and New Zealand allowed me to study worldwide some transnational social networks. Contrary to the idea that people who are settled in the Western countries and become acquainted with democracy and human

23 See A. Monsutti, "La migration afghane en Australie et en Nouvelle-Zélande", Afghanistan Info, Vol. 61, November 2007, 15-17. 
rights may play a mitigating role on conflict in their home country, ${ }^{24}$ the ethnic faultlines are sometimes exacerbated in the wider Afghan diaspora, where previous agricultural and commercial complementarities disappear. Although the Afghan migratory networks have acquired a transnational dimension, they seem to divide along ethnic lines: Pashtuns, Tajiks, Hazaras, Uzbeks and others rarely rub shoulders along the way. In both Afghanistan and the host countries, competition among the various components of society has become more pronounced. Forced migration has led to a process of urbanization and detribalization. It may foster a broader identity with reference to the Afghan nation, but concrete existence is based on narrow social ties. There is a line of tension between an abstract sense of Afghan-ness developed in exile while everyday life tends to be fragmented by group of origin.

Too great a stress on the ethnic dimension does, however, mask the reality of the solidarity networks, which are usually organized around infra-ethnic aspects such as lineage, marital ties or residential proximity. Regional origin also often carries greater weight than ethnic affiliation. People from Logar or Herat, for example, may spend time together whether they are Pashtuns or Tajiks - and the same is true of Uzbeks, Turkmens and Tajiks from the North of Afghanistan. At the macrosocial level, several faultlines are especially visible: the mistrust with which minority groups view Pashtuns, who themselves tend to feel that their claims are insufficiently acknowledged by the Afghan authorities; and probably more importantly the difference between urban and rural populations; the tense relations between the Sunni majority and the Shiite minority; the wide gap between Afghans who have lived in the West and those who have remained in Afghanistan or neighbouring countries, the conflicts of interest between diaspora elites and internal commanders. At the microsocial level, the really operational solidarity groups are based on a set of overlapping criteria (kinship and residential proximity, but also religious affiliation, educational level, and so on), which cannot be simply reduced to the dimension of ethnicity, tribe or lineage.

\section{Linking mobile people through money transfers ${ }^{25}$}

Money transfers are a matter of interest for at least four reasons: (1) they reveal the existence of social networks linking faraway places; (2) they are economically important for the areas from which the migrants originate; (3) they sustain migration as a strategy of domestic groups; and (4) they stimulate and orient future movement, since migrants pass on information about the possibilities in various regions.

24 The potential positive role of diasporas in conflict resolution and peace-building is often put forward in the literature produced by humanitarian organizations and think tanks. See for instance P. Weiss Fagen, M. N. Bump, Remittances in Conflict and Crises: How Remittances Sustain Livelihoods in War, Crises, and Transitions to Peace, Washington, International Peace Academy, 2006.

25 For further description of the remittance system among the Afghans, see S. M. Maimbo, The Money Exchange Dealers of Kabul: A Study of the Hawala System in Afghanistan, Washington, World Bank, 2003; A. Monsutti, "Cooperation, Remittances, and Kinship among the Hazaras", op. cit.; War and Migration, op. cit., 173-205. 
In the 1990s, when an Afghan working in Iran (kârgar) wished to send his savings back to his family in Afghanistan, he could not use the official banking system since he was unlikely to have any identification papers and, in any case, the banking system was not operating in Afghanistan. He therefore entrusted his money to a businessman specializing in informal remittances and known locally as a hawâladâr (from the Arabic hawâla, "transfer" and by extension "letter of credit, cheque"). Half-merchant, half-banker, his expertise in the transfer of funds has kept money and goods flowing without interruption between Iran, Pakistan and Afghanistan, a role that goes back a long way but acquired unprecedented dimensions during the war. Both kârgar and hawâladâr must belong to the same lineage or come from the same valley. If the relationship was less close than that, a middleman was needed.

The hawâladâr passed on a letter to his partners, stating the details of the transaction and gave another one to the kârgar, which he sent to his family in Afghanistan via a friend going back home. The commission charged is very low (most of the time less than 3 per cent), as the hawâladâr's profit is earned from the trade itself, and depends on how distant is the deadline for repayment and how close the relationship is between the kârgar and the hawaladâr. The hawaladâr might use this money to buy some merchandise (plastic shoes, shirts, cloth, water coolers, etc.) and export them, or directly send the money through the official banking system to Pakistan, where one of his partners (always a close relative) retrieved the money. He used it to make a profit through currency exchange and finally bought some goods (wheat, rice, cooking oil, sugar, tea, but also shoes, cloth, cooking pots, etc.). He dispatched them by lorry to the family village in Afghanistan, where a third partner ran a shop. The goods were sold and the proceeds were used to reimburse the kârgar's family.

In the absence of any external guarantee from the State, an atmosphere of trust was essential to ensure that the transaction was respected. Such trust could only arise if the interaction occurred regularly and over a long period of time. Members of each social and ethnic group dealt with members of other groups only when strictly necessary, such as to cross borders or travel in hostile areas. Despite the trauma of war and exile, the Afghans had thus managed to take advantage of their geographic dispersion and the resulting economic diversification by developing new transnational cooperation structures.

Beyond their economic dimension, money transfers play a crucial role in producing and reproducing social relations despite the context of dispersion and (very often) war. It is true that, in the Afghan case, the hawâla system would be better if it included banking facilities to convert money into loan and investment funds that could be used to rebuild infrastructure. Although the emigration of young men may pose long-term problems for the reconstruction of Afghanistan, it is still a survival strategy that has proved its effectiveness. The hawâla system has enabled many families to feed themselves, whereas humanitarian aid mainly focused on refugees during the Soviet occupation, then gradually dried up during the 1990s before making a chaotic reappearance after the fall of the Taliban in 2001. International aid has certainly helped many Afghans to cope with periods 
of acute crisis, but the multiplication of rival NGOs and a lack of coordination mean that the overall results have been often rather poor. ${ }^{26}$ Remittances through the hawâla system are considerably larger, and much better distributed, than the total sum of humanitarian aid.

We have seen that economic exchange and social ties may be conceived in correlation. Often, commodities and people circulate in opposite directions. It is precisely the case in the remittance system among the Afghan migrants, which fulfils an essential role. It is a complex interlace of solidarity and competition, trust and mistrust, whose study enables us to understand how Afghan society has not sunk into Hobbesian chaos despite war and migration. Dispersion and mobility may be seen as an asset with a social, economic and political dimension.

\section{Beyond the three solutions to the refugee problem}

The migration of Afghans is neither definitive nor temporary; it is more appropriate to speak of recurrent multidirectional movement. Few Afghan refugees never return after their initial departure, and there are few domestic units within Afghanistan without at least one member abroad. Migration and exile are therefore not usually followed by integration into a host country or definitive return to Afghanistan; movement is continual and eventually leads to the constitution of a genuinely transnational community. Drawing upon the example of the Hazaras, we have seen how the Afghans have established a "circulatory territory", to borrow an expression from Tarrius. ${ }^{27}$ By maintaining a certain dispersion of family members, they take advantage of spatial and economic diversification at the same time that they diminish the risks associated with insecurity and poverty.

Shifting away from a focus on the moment of departure and the motivations of refugees to leave their country of origin, the multi-sited study of ongoing mobility and domestic strategies shed new light on one of the most massive movement of people in the late twentieth century. Having initially followed the same people in three places (Afghanistan, Pakistan, Iran) and then beyond (Western countries), having studied the transnational networks (the movement of people, of goods and money, and of information), I may base the three initial claims on ethnographic evidences. First, the normality of movements and the prior existence of transnational networks in the region. Second, the incredible resilience and inventiveness of the Afghan population, who have largely relied on themselves to face the most trying conditions in war and exile, especially illustrated by the hawâla system. Finally, the relevance of migratory movements and of transnational networks for the reconstruction of Afghanistan (for both economy and social life: money, new skills, etc.).

26 See A. Donini, The Policies of Mercy: UN Coordination in Afghanistan, Mozambique, and Rwanda, Providence, Watson Institute for International Studies, 1996.

27 A. Tarrius, "Territoires circulatoires des entrepreneurs commerciaux maghrébins de Marseille: du commerce communautaire aux réseaux de l'économie souterraine mondiale", Journal des anthropologues, Vol. 59, 1995, $15-35$. 
The present article is based on a research conducted since the mid-1990s, after the end of the Cold War, and among a precise population. Nevertheless, similar results could have been reached following the same methodological approach in the 1980s and among other Afghan groups. The refugees are not mere victims, they have social, economic and political assets that they are able to mobilize. Mobility is one of them, blurring the boundary between the categories of refugees and migrants: refugee camps were part of larger social networks organized on a diversified repartition of tasks between members of domestic units. Some people stayed behind in the place of origin for fighting or looking after the fields; some went to the Afghan Refugee Villages in Pakistan and received food rations and housing; some went further to Iran, Kuwait, the United Arab Emirates or Saudi Arabia to earn a livelihood benefiting to the whole dispersed family through the hawâla system.

Policy options regarding Afghan migration have generally been framed within the "conflict-refugee" approach, which presumes that Afghan refugees arrived in Pakistan or in Iran in order to escape from war, and that they will return once the fighting is over. The research with a multi-sited perspective breaks from this view by approaching the subject more broadly from the perspective of "transnational networks" and acknowledging the complexity of the experience for the population of Afghanistan. The reasons for migration cannot be reduced to exposure to armed conflict. While violence and insecurity provided the backdrop to migration from the late 1970s onwards, the precise ways in which people were affected varied between individuals, families, social classes and geographical origin. Furthermore, the decision to leave Afghanistan was not unrelated to prior economic expectations about the destination and pre-existing connections. It is common to observe complex patterns of movement, including repeated departure and repatriation. Pre-existing social networks, which cannot be reduced to kinship, tribe, ethnicity, religion or political affiliation, have been critical in protecting, facilitating and sustaining Afghans on the move. Many examples of people travelling back and forth between their place of origin in Afghanistan, Pakistan or Iran have been documented, despite the fact that Afghans have been, since late 2001 and the fall of the Taliban, increasingly vulnerable to police harassment in their host countries.

The refugee perspective that informs the current policy paradigm is too simple a framework to incorporate the multiple dimensions and complexity of the Afghan migration experience. It is unrealistic to expect that a complete cessation of all conflict and political uncertainty within Afghanistan will automatically lead to the return of all people of Afghan origin who are currently living in Pakistan and in Iran. It would be more accurate to see migration between Afghanistan, Pakistan and Iran as an ongoing historical phenomenon, whose scale dramatically increased with war but which will continue, as it did before, even in the absence of military and political crises. Such a dimension could be acknowledged by regional governments in order to move away from the present-day framework and to pay more attention to the actual strategies and obstacles of Afghans. 
Afghan movement partially blurs the boundary between forced and voluntary migration, as the social strategies of people labelled as refugees and those of economic migrants are often similar. Considering the fact that ongoing migration was an efficient survival strategy for so many people, that it may be seen as a tool of reconstruction, and that it is a constitutive feature of Afghan social life, there is a real necessity to look beyond the three solutions to the refugee problems usually recommended and promoted by UNHCR: voluntary repatriation to the country of origin, integration in the host country or resettlement in a third country. Such a formal framework is not sufficient for managing the present situation, as it is based on the idea that solutions are found when populations' movements come to an end. A more comprehensive solution based on an understanding of social practices and strategies developed by the people labelled as refugees is necessary.

Based on its experience in the region and the evolution of the political situation, the UNHCR itself is aware of the limitations of its own action and has acknowledged the necessity of defining a new approach:

Return to Afghanistan is a much more complex challenge than previously recognised. This is attributable not only to the challenges inside Afghanistan but also to the changing nature of population movements and social and economic shifts induced by protracted exile. ... There have been three major causes of population movements from Afghanistan - political conflict and violence, natural disasters, and economic migration. Many Afghans cross borders to look for seasonal employment, to trade, to access services, and to maintain social and family connections. These networks may have become a critical component in the livelihood systems of many Afghan families, including returnees. ${ }^{28}$

The absorption capacity inside Afghanistan is limited, and the national economy needs the inflow of cash and commodities financed by migrants. Full repatriation is neither feasible nor desirable. Implemented at all costs, it could destabilize the fragile equilibrium of the renascent Afghan State and have negative effects on the neighbouring countries.

Even if the causes of migration are addressed to the greatest extent possible in Afghanistan, and if the government of Kabul is gradually able to provide more effective, authoritative and democratic guidance, migration will undoubtedly continue because of population growth, the underdevelopment of the country, persistent lack of rule of law, and potential natural disasters, as well as corresponding demands of Pakistani and Iranian economies. As we have seen, it would be naive to see in the pervasiveness of mobility and transnational networks the ideal breeding ground for national unity and peace-building in Afghanistan. But it would be equally prejudicial to overlook the fact that it is an important aspect of social strategies and may be a factor for the reconstruction of Afghanistan and for the stability of the whole region.

28 UNHCR, Afghanistan: Challenges to Return, op. cit., 1. 